\title{
Comparison of technical-economic performance of traditional and innovational sprinkler extinguishing units
}

\author{
Kseniia Zorina ${ }^{1 *}$, Maria Vasilieva $^{1}$, Igor Babikov ${ }^{2}$, and Anton Tanklevskiy ${ }^{2}$ \\ ${ }^{1}$ Peter the Great St.Petersburg Polytechnic University, Politekhnicheskaya 29, St.Petersburg, 195251, \\ Russian Federation \\ 2“"Gefest” Enterprise group, Serdobolskaya 65A, St.Petersburg, 197342, Russian Federation
}

\begin{abstract}
One of the most important tasks during construction and maintenance of buildings and compartments is a fire-safety provision of the premise. Generally, the most reliable, effective and economical method of fire safety provision is implementation of automatic extinguishing units (AEU), water-based ones in particular, which effectively protect people and material assets. The present article contains an economic evaluation of applicability of innovational AEU with electrical activation and monitoring of activation (AEU with EA and MA) in comparison with traditional AEU. Results of hydraulic calculations, the choice of a general pressure of the system, water discharge, pipeline diameter and their cost are presented.
\end{abstract}

\section{Introduction}

The use of automatic fire extinguishing units is an important factor in the effective detection and prevention of fire development. Sprinkler extinguishing units are the most widespread ones to date.

Together with numeral advantages sprinkler extinguishing has two considerable drawbacks - low sensitivity and high inertia. In some cases, it leads to a significant delay in extinguishing start, while the area of the fire grows faster than the area extinguished by activated sprinklers, which leads to uncontrolled development of fire. In particular, this situation is typical for premises with a big height of overlap and significant fire load.

As the cost of implementation of a single sprinkler unit (depending on the area of the protected object) reaches 50-100 million rubles, tens of billions of rubles a year are spent inefficiently across the country, without providing reliable fire protection of the premises. In this regard, one of the directions of development of fire automatics is the introduction of fire extinguishing systems that do not have analogs, in which modern technological advances are fully used. The functioning of such systems is based on sprinklers with electrical activation and monitoring of activation, equipped with response accelerators based on satellite fire detectors [1].

AEU with electrical activation differs from traditional ones by launching sprinklers under an electrical signal supply regardless environment temperature in the sprinkler installation

* Corresponding author: zorina_kv@mail.ru 
area [2]. It allows reducing the time before the beginning of extinguishing and using sprinklers for blocking a fire spread effectively [3,4].

A fire alarm from fire detectors included to a fire alarm system, or integrated with controlled sprinklers, an address signal from the first sprinkler or in any other reliable fire alarm signal [5] can be used as a trigger signal. The main element of the controlled sprinkler is an electric heater installed on a heat-sensitive bulb that performs the function of a shut-off valve. When the activation pulse is applied, the bulb is forced to heat up, leading to its destruction [6]. Also, depending on the tasks to be performed by the fire extinguishing unit, controlled sprinklers can additionally be equipped with an activation monitoring device (to generate signals about activated sprinklers) and / or satellite fire detectors that will activate the sprinkler immediately after a fire is detected [7-10].

At present time, the most common automatic fire extinguishing units are water-based ones. This is due to their availability, safety, low cost, even with the huge discharge of a fire extinguishing agent (EA) for extinguishing and because of practically unlimited or fully sufficient supply of EA for these purposes in in external networks and reservoirs [11-14].

It is known that the choice of AEU is influenced by its technical characteristics and capabilities, which in turn determine the economic component of this system. Often, the values of indicators such as water flow, the required amount of water, and the diameters of pipelines can be decisive when choosing an extinguishing unit. Considering the novelty of the AEU with EA and MA in the market of fire automatics, the assessment of the economic component is an urgent task, as such unit is the most reliable and efficient in comparison with traditional AEU. Thus, the purpose of the study was the economic assess, emt of AEU with electrical activation and traditional AEU.

\section{Methods}

The basis of this study was the requirements for ensuring the fire safety of a real object, which was the building of a shopping center (SC). According to known methods, hydraulic calculations, the choice of the total pressure of the entire fire extinguishing system, the flow rate of the organic substances and the size of the pipes were carried out both for the traditional AEU and for the AEU with EA and MA [3,15]. Fire extinguishing agent was water taken from the municipal pipeline [16].

Differential pressure was calculated for the selected pipes. Then, on the basis of hydraulic calculations, a pumping station was selected. Ultimately, the cost of each system as a whole was estimated [15].

There is a heating system in the protected compartment thus a wet sprinkler system was designed in [17].

The height of the compartment was $6 \mathrm{~m}$ and the area was $10.044 \mathrm{~m}^{2}$ (the dimensions in a plan were $54 \times 186 \mathrm{~m}$ ); a group of premises according to Set of Rules 5.13130.2009 - 1 (premises of shops); fire resistance of the building is not lower than II; constructive fire hazard class - $\mathrm{C} 0$.

4 types of sprinklers were included in calculations: pendent sprinkler SVO0-RNo 0.42R1/2 /P57.V3-«Aqua-Gefest»; water-mist pendent sprinkler SVS0-RNo0.1 - R 1 /2/P57.V3-«Aqua-Gefest»; pendent sprinkler with electrical activation SEVO0-RNo 0.3R1/2 /P57.V3 - «Aqua-Gefest»; water-mist pendent sprinkler with electrical activation SEVS0-RNo0.1-R 1/2/P57.V3-«Aqua-Gefest».

The study considered sprinklers of AEU-EA «Gefest» for compartments higher than 10 $\mathrm{m}$, which allow not to increase water consumption, sprinkling intensity and minimum area, but to accept parameters as for rooms $10 \mathrm{~m}$ high [18-22]. For rooms with a height of less than $10 \mathrm{~m}$ of the $1 \mathrm{st}$ and 2 nd groups of premises reduce water consumption by 1.5-2 times as compared with the standard for Set of Rules 5.13130 [3,23-25]. 
In accordance with the project, it was envisaged that the pressure in the system should be maintained by a pump station, which consists of two pumps - the main and the reserve ones. On the water supply line, another pump and an expansion tank were provided. The sprinkler system has a special control unit that sends a signal to the pump about the pressure drop. When some sprinklers are activated, the pressure in the system drops and the pump starts up. The control unit consists of valves, fittings, pressure gauges, pressure sensors and pipes.

\section{Results and Discussion}

The traditional sprinkler system consists of sprinklers, welded couplings, pipes and a pumping station. In addition, pipes must be attached to building structures with special pipe hangers. AEU-WM (water-mist) pipelines must be made of galvanized or stainless steel.

The cost of AEU systems with electrical activation also consists of the cost of sprinklers, pipelines and pumping station. Comparison of pumping stations for AEU is presented in table 1 .

In addition, it is necessary to take into account the cost of electrical equipment for monitoring of automatic devices. In order to monitor the system, programmable hardware complex «Olimp» is used.

Such complex makes it possible to activate sprinklers according to a pre-set algorithm. Using this complex a traditional sprinkler unit is transformed into a modern intellectual addressable system, where each sprinkler has its own address and is constantly monitored.

«Olimp» system includes: control unit BKU-3200, local controller KL-240 SA, relay module MR.

Control unit BKU-3200 is a central device of the programmable complex «Olimp» and is used for monitoring and control of local controllers KL-240 SA.

KL-240 SA is used for monitoring and control of peripheral devices of an extinguishing system with electrical activation. It works together with a relay module (MR), which is used for supply of addressable devices.

Relay module is used for feeding of peripheral devices of an extinguishing system with electrical activation.

Table 1. Comparison of pump stations.

\begin{tabular}{|c|c|c|c|c|}
\hline & $\begin{array}{c}\text { AEU system } \\
\text { with sprinklers }\end{array}$ & $\begin{array}{c}\text { AEU system } \\
\text { with sprinklers } \\
\text { with electrical } \\
\text { activation }\end{array}$ & $\begin{array}{c}\text { AEU system } \\
\text { with water- } \\
\text { mist sprinklers }\end{array}$ & $\begin{array}{c}\text { AEU system } \\
\text { with water-mist } \\
\text { sprinklers with } \\
\text { electrical } \\
\text { activation }\end{array}$ \\
\hline $\begin{array}{c}\text { Pressure, } \\
\text { m Hg }\end{array}$ & 63.2 & 74 & 77.5 & 70.87 \\
\hline $\begin{array}{c}\text { Discharge, } \\
\mathbf{m}^{3} / \mathbf{h} \\
\end{array}$ & 40.2 & 21.17 & 15.5 & 7.72 \\
\hline $\begin{array}{c}\text { Pump } \\
\text { station }\end{array}$ & $\begin{array}{c}\text { «Sprut-NS» } \\
\text { version }[2 \text { xHelix } \\
\text { V } 3605 / 2+ \\
\text { Helix V } 612+ \\
\text { Membrane } \\
\text { tank]100M + } \\
\text { Alarm command }\end{array}$ & $\begin{array}{c}\text { «Sprut-NS» } \\
\text { version } \\
{[2 \mathrm{xHelix} \mathrm{V}} \\
1610+\text { Helix V } \\
413+ \\
\text { Membrane } \\
\text { tank]80M + }\end{array}$ & $\begin{array}{c}« \text { Sprut-NS» } \\
\text { version } \\
{[2 \mathrm{xHelix} \mathrm{V}} \\
1608+\text { Helix V } \\
413+ \\
\text { Membrane } \\
\text { tank]80M + }\end{array}$ & $\begin{array}{c}\text { «Sprut-NS» } \\
\text { version [2xHelix } \\
\text { V } 1606+\text { Helix V } \\
411+\text { Membrane } \\
\text { tank] } 80 \mathrm{M}+ \\
\text { Alarm command } \\
\text { signal cabinet }\end{array}$ \\
\hline
\end{tabular}




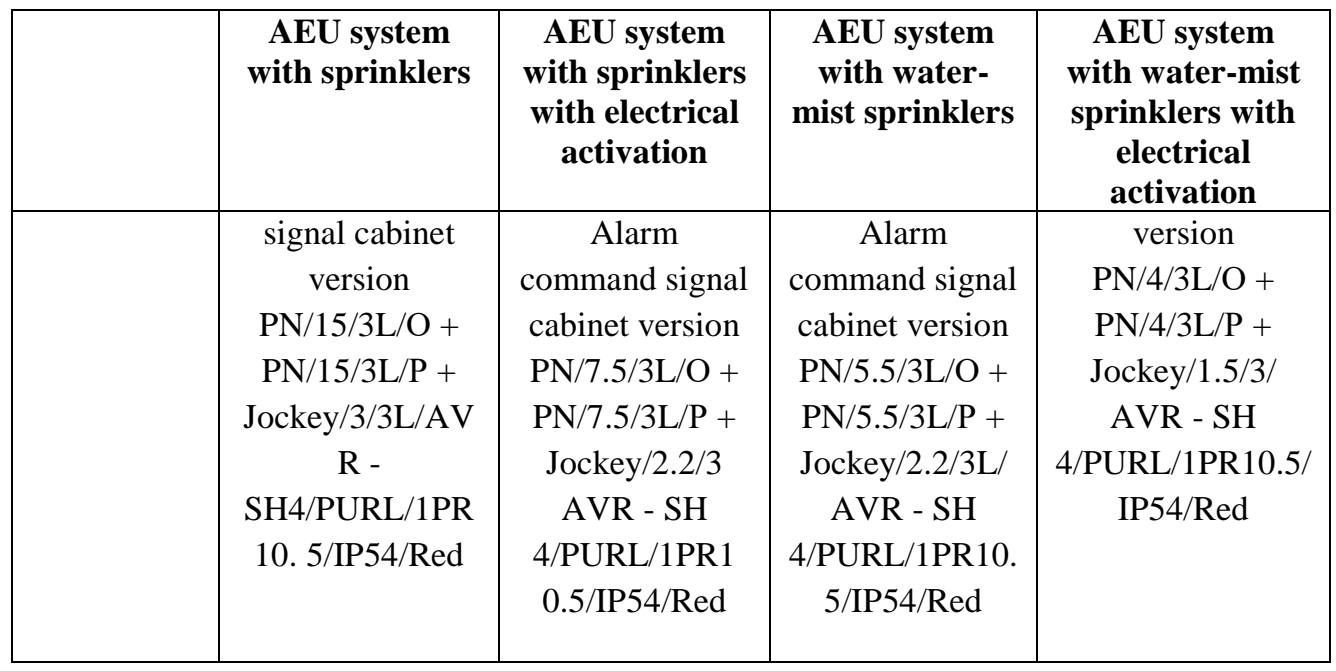

An economic calculation was made for four installations, the results of which are presented in table 2. Equipment prices are presented by Russian companies [26-28].

The total economic costs of traditional AEU systems and AEU systems with electrical activation are presented in summary table 2 . In case of insufficient water volume, in order to ensure the operation of a traditional sprinkler unit, it may be necessary to install an additional reservoir for storing fire extinguishing substances, the cost of which, along with the costs considered, is also presented in table 2. Prices for tanks are presented by the company [29].

Table 2. Cost of main components of AEU with steel pipelines.

\begin{tabular}{|c|c|c|c|c|}
\hline Cost, rub. & $\begin{array}{c}\text { AEU system } \\
\text { with } \\
\text { sprinklers }\end{array}$ & $\begin{array}{c}\text { AEU system } \\
\text { with } \\
\text { sprinklers } \\
\text { with } \\
\text { electrical } \\
\text { activation }\end{array}$ & $\begin{array}{c}\text { AEU system } \\
\text { with water- } \\
\text { mist } \\
\text { sprinklers }\end{array}$ & $\begin{array}{c}\text { AEU system } \\
\text { with water- } \\
\text { mist sprinklers } \\
\text { with electrical } \\
\text { activation }\end{array}$ \\
\hline Sprinklers & 200508.00 & 340256.00 & 239880.48 & 373744.00 \\
\hline Pipelines & 856843.53 & 675104.27 & 807200.90 & 725424.50 \\
\hline $\begin{array}{c}\text { Pump station } \\
\text { Electronics }\end{array}$ & 1117342.00 & 768888.00 & 700802.00 & 645696.00 \\
\hline $\begin{array}{c}\text { Reservoir for } \\
\text { extinguishing agent, } \\
\text { rub. }\end{array}$ & 359600.00 & 198400.00 & 111400.00 & 76600.00 \\
\hline \begin{tabular}{c} 
Total, rub. \\
\hline
\end{tabular} & 2534293.53 & 2899229.07 & 1859283.38 & 2595072.30 \\
\hline
\end{tabular}

The total cost of AEU systems with sprinklers with electrical activation using steel pipelines turned out to be $15 \%$ higher than the cost of traditional sprinkler systems, and the difference in the cost of installations with water-mist was almost $40 \%$. Units with electrical activation are more complicated and expensive because of the need to purchase electrical 
equipment than sprinkler units with traditional sprinklers which are activated only under certain temperature [30].

Due to the technical progress of the water extinguishing system, other products than metal ones can be used. One of the latest trends has been widely used - the use of fireresistant plastic pipes in the supply, feeding and distribution pipelines of sprinkler AEU. Fire-resistant plastic pipes are not susceptible to corrosion, and the fire-extinguishing system works effectively during the entire service life (at least 50 years), without requiring expenses for repairing joints and painting. The ease of installation and the strength of the connections make such systems a worthy alternative to metal pipelines.

In conjunction with this fact, calculations of the cost of AEU system with plastic pipelines were carried out. FIREPROFF pipelines manufactured by OJSC «Potok - Pipe Company» were in the basis of calculations.

A hydraulic calculation was made for fire extinguishing systems using plastic pipes, the specific characteristics of the pipelines were taken from the technical conditions [31]. Basic parameters, such as water consumption and pipe diameters, have not changed as compared with calculations of steel pipelines. However, the hydraulic parameters of pumping stations have changed and are presented in table 3.

Table 3. Comparison of parameters of pump stations for AEU system with plastic pipelines.

\begin{tabular}{|c|c|c|c|c|}
\hline & $\begin{array}{c}\text { AEU system } \\
\text { with sprinklers }\end{array}$ & $\begin{array}{c}\text { AEU system } \\
\text { with sprinklers } \\
\text { with electrical } \\
\text { activation }\end{array}$ & $\begin{array}{c}\text { AEU system } \\
\text { with water-mist } \\
\text { sprinklers }\end{array}$ & $\begin{array}{c}\text { AEU system with } \\
\text { water-mist } \\
\text { sprinklers with } \\
\text { electrical } \\
\text { activation } \\
\end{array}$ \\
\hline $\begin{array}{l}\text { Pressure, } \\
\text { m Hg }\end{array}$ & 35.7 & 36 & 58.12 & 51 \\
\hline $\begin{array}{c}\text { Discharg } \\
\text { e, } \mathbf{m}^{3} / \mathrm{h}\end{array}$ & 38.8 & 20.77 & 15.34 & 7.67 \\
\hline $\begin{array}{c}\text { Pump } \\
\text { station }\end{array}$ & $\begin{array}{c}\text { «Sprut-NS» } \\
\text { version [2xHelix } \\
\text { V 5202 + Helix } \\
\text { V } 1005+ \\
\text { Membrane } \\
\text { tank]100M + } \\
\text { Alarm command } \\
\text { signal cabinet } \\
\text { version } \\
\text { PN/7.5/3L/O + } \\
\text { PN /7.5/3L/P + } \\
\text { Jockey/2.2/3L/A } \\
\text { VR - } \\
\text { SH4/PURL/1PR } \\
\text { 10. 5/IP54/Red }\end{array}$ & $\begin{array}{c}\text { «Sprut-NS» } \\
\text { version } \\
{[2 x H e l i x ~ V} \\
1605+\text { Helix V } \\
407+ \\
\text { Membrane } \\
\text { tank] } 80 \mathrm{M}+ \\
\text { Alarm } \\
\text { command signal } \\
\text { cabinet version } \\
\text { PN /4/3L/O + } \\
\text { PN /4/3L/P + } \\
\text { Jockey } \\
\text { /1.1/3L/ABP - } \\
\text { SH4/PURL/1PR } \\
10.5 / \text { IP54/Red }\end{array}$ & $\begin{array}{c}\text { «Sprut-NS» } \\
\text { version [2xHelix } \\
\text { V } 1606+\text { Helix } \\
\text { V } 410+ \\
\text { Membrane } \\
\text { tank]80M + } \\
\text { Alarm command } \\
\text { signal cabinet } \\
\text { version PN } \\
\text { /4/3L/O + PN } \\
\text { /4/3L/P + Jockey } \\
\text { /1.5/3L/AVR - } \\
\text { SH4/PURL/1PR } \\
\text { 10. 5/IP54/Red }\end{array}$ & $\begin{array}{c}\text { «Sprut-NS» } \\
\text { version [2xHelix V } \\
1605+\text { Helix V } \\
410+\text { Membrane } \\
\text { tank]80M + Alarm } \\
\text { command signal } \\
\text { cabinet version PN } \\
\text { /4/3L/O + PN } \\
\text { /4/3L/P + Jockey } \\
\text { /1.5/3L/AVR - } \\
\text { SH4/PURL/1PR10 } \\
.5 / \text { IP54/Red }\end{array}$ \\
\hline
\end{tabular}

After that, an economic calculation was made for four sprinkler units with plastic pipes. Prices for equipment are presented by Russian companies [26,27]. Results of the calculation are presented in table 4. 
Table 4. Cost of main components of AEU with plastic pipelines.

\begin{tabular}{|c|c|c|c|c|}
\hline Cost, rub. & $\begin{array}{c}\text { AEU system } \\
\text { with } \\
\text { sprinklers }\end{array}$ & $\begin{array}{c}\text { AEU system } \\
\text { with } \\
\text { sprinklers } \\
\text { with electrical } \\
\text { activation }\end{array}$ & $\begin{array}{c}\text { AEU system } \\
\text { with water- } \\
\text { mist } \\
\text { sprinklers }\end{array}$ & $\begin{array}{c}\text { AEU system } \\
\text { with water-mist } \\
\text { sprinklers with } \\
\text { electrical } \\
\text { activation }\end{array}$ \\
\hline Sprinklers & 200508.00 & 340256.00 & 239880.48 & 373744.00 \\
\hline Pipelines & 2515763.20 & 1678822.72 & 1353255.92 & 1146831.32 \\
\hline Pump station & 1017160.00 & 593068.00 & 639442.00 & 617494.00 \\
\hline Electronics & 0.00 & 916570.80 & 0.00 & 773607.80 \\
\hline Total, rub. & 3733431.20 & 3528717,52 & 2232578,40 & 2911677,12 \\
\hline
\end{tabular}

The total cost of AEU systems with sprinklers with electrical activation using plastic pipes turned out to be $5 \%$ cheaper than the cost of traditional sprinkler systems. This results from the fact that the main expenses fall to pipelines and pump stations. If you reduce water consumption, you can reduce the diameters of pipelines, choose more budgetary options for pumping units, since the requirements for their parameters will decrease, as a result, the price will decrease. The difference in the cost of units with water-mist sprinklers was almost $30 \%$. Fire-prevention plastic pipes are more expensive than metal ones, but they have advantages: lightness of construction, delivery dates, safety of welding (the ability to work at existing facilities), absence of leaks and blockages generated by corrosion products. Due to the simplicity and speed of installation, the cost of work is 2 times cheaper than in the case of the use of metal elements. Ultimately, the total estimated cost of plastic materials with installation works is comparable to the use of systems that include metal piping.

\section{Conclusions}

Automatic fire extinguishing units with electrical activation and monitoring of activation have no analogues in the world, but they are very promising. AEU with EA and MA were included to the national regulatory documentation in 2015. Now GOST R is taking part in development of a section of ISO 6182-1 standard, which is devoted to sprinklers with electrical activation. Due to the fact that there is no experience of a widespread use of innovative AEUs with EA, designers have difficulty choosing an efficient and economically sound water extinguishing system.

The comparison of the technical and economic performances of traditional AEU and AEU with EA given in the work clearly demonstrates the increase in cost in the case of using an innovative technology, which, however, according to the calculations can be reduced by replacing steel reinforcement with a polymeric one and also compensated by the increased efficiency of AEU with EA.

\section{References}

1. L. Tanklevskiy, M. Vasiliev, L. Meshman, A. Snegirev, A. Tsoi, A Novel Methodology of Electrically Controlled Sprinkler Activation, London, 1263-1268 (2013) 
2. Fire Code 88-2001, Fire extinguishing and alarm units. Design rules and regulations (with Amendment N1), Moscow (2003)

3. Set of Rules SP 5.13130.2009 Fire protection systems. Automatic fire alarm and extinguishing units. Design rules and regulations, Moscow (2009)

4. S. Tsarichenko, V. Bylinkin, Fire-explosion safety, 3, 70-73 (2003)

5. V. Fomin, Brief review of automatic fire extinguishing development, Academy of State fire protection service of EMERCOM of Russia, 7-14 (2015)

6. S. Kopylov, L. Meshman, A. Snegirev, L. Tanklevskiy, A. Tarantzev, A. Tsoi, Fire safety, 1, 72-79 (2015)

7. S. Kopylov, L. Tanklevskiy, M. Vasiliev, V. Zima, A. Snegirev, Advantages of Electronically Controlled Sprinklers (ECS) for Fire Protection of Tunnels, New York (2012)

8. A. Abramov, K. Rushkina, I. Babikov, Efficiency evaluation of implementation of satellite fire detectors in AEU with electrical activation, St. Peterburg (2016)

9. V. Baburov, V. Baburin, V. Fomin, V. Smirnov, Production and fire automatics. Part II. Automatic fire extinguishing units, Moscow 298 (2007)

10. N. Bubyr, V. Baburov, V. Potapov, Production and fire automatics. Part II, Fire automatics, Moscow (1986)

11. GOST R 50680-94, Automatic extinguishing units. General technical requirements, Moscow (1994)

12. S. Smirnov, Fire safety, 144 (2010)

13. S. Sobur, Automatic fire extinguishing units, 400 (2004)

14. L. Tanklevskiy, Science week of SPbSTU collection of reports from the international scientific forum, St. Peterburg, 19-25 (2014)

15. M. Lebedeva, I. Babikov, Materials from the international scientific conference. Higher school of techno-sphere safety. St. Petersburg, 204 (2017)

16. GOST 12.4.009-83, System of labour safety standards. Fire equipment for protection of premises. Main types. Arrangement and maintenance, Moscow (2005)

17. V. Pakhomov, V. Bylinkin, Fire-explosion safety, 76-80 (2008)

18. D. Kareeva, V. Glazkova, Reconstruction and restoration of historical buildings of transport infrastructure (2017)

19. A. Bolotin, O. Mironova, S. Lukina, L. Yarchikovskaya, Healthy lifestyle skill building technology for university students: Conceptual and procedural aspects, 18-20 (2016)

20. R. Gilemkhanov, R. Bagautdinov, V. Kankhva, Autodesk Revit and Robot Structural Analysis in Design of Framed Buildings, 1036-1045 (2018)

21. A. Gorshkov, V. Murgul, Calculation of Heat Energy Consumption by a Typical Historical Building with a Courtyard, 577-591 (2018)

22. VNPB 40-16, Automatic fire extinguishing units AEU «Gefest», Design, Company standard STO 420541.004, St. Petersburg (2015)

23. L. Tanklevskiy, M. Vasiliev, Sprinkler with electrical activation, Patent №2379080 Russian Federation, St. Petersburg (2010)

24. L. Tanklevskiy, M. Vasiliev, Sprinkler fire extinguishing unit, Patent №129005 Russian Federation, St. Petersburg (2013)

25. L. Tanklevskiy, A. Arakcheev, Sprinkler with monitoring of activation, Patent №2610812 Russian Federation, St. Petersburg (2017) 
26. L. Tanklevskiy, A. Tsoy, A. Snegirev, Fire Safety J., 614-623 (2017)

27. E. Voskresenskaya, L. Vorona-Slivinskaya, Development of national standards related to the integrated safety and security of high-rise buildings, (2018)

28. A. Lucherini, L. Giuliani, G. Jomaas, Fire Safety J., 95, 42-50 (2018)

29. T. Gong, Q. Xie, X. Huang, Fire Safety J., 95, 113-121 (2018)

30. S. Tzarichenko, V. Bylinkin, Fire-explosion safety, 3, 70-73 (2003)

31. VNPB 19-14, Design, Installation and maintenance of plastic pipelines FIREPROFF in fire extinguishing units, Company standard STO-TU №1/13, (2013) 